\title{
Of libraries, books, and reading: A journey of meaning making Edwin Smith
}

\section{Of libraries, books, and reading: A journey of meaning making}

In this essay I seek to demonstrate how an iterative reading of Archie L. Dick's The Hidden History of South Africa's Book and Reading Culture (2012), read through a life history lens, makes meaning of the lived experiences of South Africans-particularly during the time of the struggle against Apartheid, which is the focus of this essay. Relying on the life history approach to the recounting and exploration of South African history through the library, book, and reading culture of South Africans, I trace the complex and multi-layered experience of South Africa and its peoples as reported in The Hidden History. Interwoven with my own experiences with libraries, books, reading, and writing, I unveil the significant making of meaning in Dick's enterprise. As demanded by Dick, I confirm in this essay that South African liberation history must indeed include the roles played by librarians, books, and the experiences of ordinary South Africans in order to provide a fuller appreciation of the various influences and understanding of South Africa's past. Keywords: history, books, reading, struggle, apartheid, exile, culture, South Africa.

\section{Introduction}

Archie Dick authored The Hidden History of South Africa's Book and Reading Culture (2012). Among other things, Dick argues that "the evidence of common reading illuminates the mentalities and world views of ordinary South Africans. Why and how they participated in larger historical developments or refused to do so becomes clearer when we investigate their hidden book and reading cultures" (142). Several reviewers considered Dick's book a "watershed". Among them, Daniel Magaziner references the book as a "slim but revealing volume [in which] Dick analyses the other side of the literary exchange-not the word as written, but its reception, circulation, and life among a variety of reading publics [...] This story adds texture to our understanding of intellectual life across South African history" (1024). Isabel Hofmeyr has high praise for "Dick's marvellous book that draws together the fragmented field of scholarship on books and reading, providing a first book-length study on this topic" (215). Hofmeyr also appreciates "a fascinating chapter on the library at the Solomon Mahlangu Freedom College, [which] shows how rank-and-file readers generally escaped the serious political reading their leaders wanted them to consume and instead read lifestyle magazines" (217).

These observations accord well with my reading of The Hidden History, enabling an insightful discourse between my life history and Dick's endeavours. Reading Dick's The Hidden History iteratively through the lens of my life history with libraries and books has been illuminating about aspects of my growing up in Apartheid South Africa and my life in exile, periods, and experiences that intersect with substantial parts of Dick's treatise, particularly his Chapters 5, 6, and 7. In meditating on Dick's thesis, I have learned, as he intended, to understand the meaning and significance of these experiences and efforts by locating them in the larger story he presents. While I find my personal story embedded in Dick's efforts at unearthing and making sense of our national experience, my life history also unveils remarkable nuances, deepening my appreciation of the valuable contribution of The Hidden History in enabling a richer appreciation of the complex South African experience.

\section{Life history as a lens}

Life histories are an important source and method in qualitative research. According to Hanne Kirstine Adriansen "a life story is concerned with understanding a person's view and account of their life, the story they tell about their life". As a result, "in life history research, the intention is to understand how the patterns of different life stories can be related to their wider historical, social, environmental, and political context" (41). Life histories assist in making sense of phenomena through personal experience.

Edwin Smith is reading for a master's degree in History in the Department of Historical and Heritage Studies in the Faculty of Humanities at the University of Pretoria, Pretoria, South Africa. He is the manager of campus operations at the Mamelodi campus of the same institution.

Email: edwin.smith@up.ac.za

(iD https://orcid.org/0000-0002-8318-4137

D0l: https://doi.org/10.17159/tl.v57i2.8798 
While there continues to be debates about the shortcomings in this methodology, its utility and value persists. According to Rachel Slater, "people's life histories" have specific qualities, which enable us "to understand how the impact of social or economic change differs according to the unique qualities of individual women or men" by allowing us "to explore the relationship between individual people's ability to take action (their 'agency'), and the economic, social, and political structures that surround them" (Slater 38). For Dick, "books and reading and writing practices can $[. .$.$] be woven into the private and public pasts of ordinary South Africans. In the process,$ long-buried events and personalities are unearthed, their hidden histories revealed", and great insights emerge (7).

\section{Discovering libraries, books, and reading}

We did not have a library in our community in Duncan Village in East London. The neighbouring Indian community of Braelyn Heights, which displaced us in the East Bank location in 1970, had a community library at one end of the only shopping complex in that neighbourhood at the time. "Township readers and librarians had poor access to books and information because of racially segregated library services", which in association with "the Group Areas Act, no. 41 of 1950", in terms of which the "allocation of library physical space and book supply in black and Coloured townships was unfair", resulted in "race-sensitive" library spaces (Dick 102-3).

My mother introduced me to the library when she needed to show me where I could spend my afternoons after school, if I did not want to be stuck at home until she returned from work. I was in primary school at the time. With my visits to the library, I was fascinated by a young Indian girl whose father owned the supermarket at the other end of the shopping complex. She worked in her father's shop after school and visited the library when on break, which made me visit the library every day, just so I could lay my eyes on her. While she was working, I read to keep busy. I read all the Afrikaans Konsalik books the library had on its shelves. ${ }^{1}$

It was during these feats of devotion that I discovered the The Hardy Boys series that I later learned where written by a group of ghostwriters under the collective pseudonym of Franklin W. Dixon (The Write Editor), and James Hadly Chase's thrillers, as well as John Buchan's The Thirty Nine Steps. The library also hosted a chess club, which I joined primarily to blend in with the crowd. This was how "'the books were just the props'. This meant that the books were often incidental to the use of the library" (Dick 106).

In high school, our language arts teacher would, once a week, take us to the library to learn about this resource and encourage us to take books to read at home. Though I do not recall ever taking a book out from our school library, I greatly enjoyed visiting the library because you also got a chance for the teacher to sit next to you to talk about the book you were reading. With her that close, you could smell her perfume and be enchanted by her melodic voice. Such were the pleasures of libraries and books for me then.

While I became politically active in high school and was aware of teachers politicising students in their schools, I did not experience this as dramatically as when "teachers combined academic work with information about changes happening in the country at schools where 'liberation before education' held sway" (Dick 109). My experiences were limited to my Afrikaans teacher, who, unhappy with my performance in his class and believing I could do better if only I could fix my attitude to the language, invited me to his house after school one day, sat me down in his study and showed me one of his Adam Small collections of poetry, Sê Sjibbolet. He then explained that Afrikaans was 'our language' and that my rejection of Afrikaans as 'the language of the oppressor' was myopic and reactionary. Adam Small was my initiation to Afrikaans writing by "one of our own people".

However, some of my teachers were sympathetic to my political activity, though they were careful not to publicly display such support given the dire consequences at the time. I appreciated their clandestine support. My accounting teacher lent me her car to distribute underground material and let me hide in her house when the police were hounding me. Then there was the case of two of the ANC's military wing, Umkhonto we Sizwe (Spear of the Nation), commanders, Leon Meyer and Clifford Brown, who were students at my school before me. They both died during military operations in the struggle. Clifford Brown was killed in Durban in 1984, following his unit's rocket attack on the Mobil Oil Refinery (Hengeveld \& Rodenburg 53-4; Goldstone). Leon Meyer, operating in Lesotho, died in a raid in Maseru in 1985 along with his wife, Jacqueline Quinn (South African History Online). Having been a generation ahead of me, by the time I got to high school, only their names were etched in a paving stone at one end of the administration building.

We did not really have books at home. My father read The Daily Dispatch, our local newspaper, religiously. But he never talked about what he had read. Later, he bought the Reader's Digest Repair Manual: Complete Guide to Home Maintenance, which I used for all manner of projects around the house. When I took up woodworking in high 
school, this guide became a constant companion. I also visited the central public library in town, particularly during the examination periods, as it was a popular place for students to study during the day. However, and apart from the fact that "between 1984 and 1987, South African Defence Force (SADF) troops occupied townships to quell political resistance [and that] by 1985, there were 35372 troops in ninety-six townships around the country" (Dick 102), ostensibly making studying in the townships dangerous, I never understood the allure the library in the city had for my peers. For me, the daunting, multi-storied building did not really accord with my study habits.

I was thirteen years old when I was first arrested and tortured at the infamous Cambridge Police Station in my hometown, presumably because I was a terrorist and there had been an armed robbery at our local grocer, even though I had no idea what a terrorist was or how to operate a firearm at the time. During my incarceration, I was offered a Bible. "The Bible was usually the only reading material supplied so that detainees would reflect on the harm done to society and to fulfil the Nationalist government's Christian duty" (Dick 128). I also got tobacco and so after reading the Bible, I would tear a page from the good book and roll a zol (a hand rolled cigarette) to smoke. I literally took the word in through reading and then through smoking.

\section{Books, reading, and writing in the underground}

I was arrested seven times before I eventually left the country for exile. By then I had also learned to read banned books with a flashlight under my blanket at night at home or in secluded spaces like the nearby bush in our neighbourhood. I also ran an underground printing press in Mthatha during my short stint hiding in the area to avoid further incarceration, or worse, death, at the hands of the security police in East London. This is how I recognise the "incriminating typewriter [that] had to be thrown into the sea to evade the security police because it was used to produce a list of names of ANC members" (Dick 109), as it relates directly to my experiences in Mthatha in the 1980s.

While 'underground' in Mthatha, I worked with the Adult Literacy and Advice Centre (ALAC), under the auspices of the Transkei Council of Churches under Ezra Sigwela, a former Robben Island prisoner and Father Cas Paulsen, then stationed at the Tsolo Catholic parish. It was during this time that I also met my lifelong comrade with whom I would end up going into exile and studying in the US. At ALAC, we partnered with a national NGO, Learn and Teach, which provided literacy programs to South African communities heavily based on Paulo Freire's methodologies articulated in Pedagogy of the Oppressed and his work in Guinea Bissau.

With the aid of a comrade who was a teacher in the area, we broke into the Education Offices in Mount Frere and stole a Gestetner Roneo duplicating machine, ink, stencils, paper, and a manual typewriter-all of which we used to write and type political propaganda on the stencils and print tons of copies for distribution in the dead of night in the Mthatha neighbourhoods like Dick's "students [who] transported the pamphlets in borrowed cars and pick-up trucks, and distributed them from door to door" (Dick 108).

Our printing press, which we hid in the garage of my friend's Fort Gale home in respectable suburban Mthatha, was pointed out by one of our comrades, who the security police had arrested, badly beaten, and broken through brutal torture. I was in Johannesburg at Learn and Teach and Wits University when I was summoned back to the Transkei to attend to this setback. As soon as I arrived in Mthatha the next day, I reconnected with my comrade hiding in a relative's backyard in Norwood. With the help of Father Cas, we were able to get out of the Transkei with me swapping Cas' clerical shirt and tab collar because I could not return to East London without risking arrest. Disguised as a priest in my hometown, we arranged to fly to Johannesburg where we connected with the ANC underground to arrange our exit. We were organised and led out of the country by Peter Mokaba, who later became the president of the ANC Youth League and served as a deputy minister in the Mandela administration.

From reading The Hidden History, I recognised that "the library space, like any 'lived space', was one of meaningmaking and conflict in the 1980s. It was constantly made and unmade, claimed and disclaimed by communities" (Dick 109), albeit my formative experiences with libraries were as "foreign spaces". These were places I had to learn to navigate and spaces I employed more as "props" than spaces for challenging the political order. Nonetheless, they shaped me in their own ways. Perhaps my age had a lot to do with it as much of my experiences with libraries in South Africa were before I was seventeen years old. Having gone into exile shortly before, I spent my seventeenth birthday in a refugee camp in Dukwe in Botswana. 


\section{Libraries, books, and reading in exile}

When I went into exile in the mid-1980s, I learned that "for South Africans who fled the country during the apartheid era, 'the good thing about being away from home [was] that you [could] read pretty much anything you like"' (Dick 112). This commenced with my discovering a library in the Dukwe refugee camp in Francistown in Botswana. After being arrested in Botswana for entering that country illegally, we were kept in 'protective custody' in prison in Pitsane Molopo for three months, transferred to another prison in Gaborone, and eventually to the United Nations High Commissioner for Refugees' camp in Dukwe. While in Dukwe, we were 'processed' by the ANC comrades tasked with this responsibility. With the influx of young South Africans fleeing into exile since the Soweto Uprising in 1976, there was the corresponding threat posed by government agents infiltrating the liberation movements in exile. Security screening was a critical measure to address this ever-present and real danger.

We spent several months in Dukwe. Due to our precarious situation where the South African government agents were all over the place in Botswana, kidnapping and maiming South African exiles, we had to be careful about our movements. The library, being a public space, was better avoided than visited unnecessarily. When not occupied with reading, comrades would pass the time telling stories. My lifetime comrade, with whom I 'skipped' the country, had a remarkable ability to tell stories. This is how I listened to instalment after instalment of S. E. K. Mqhayi's Ityala lamawele (The Lawsuit of the Twins), which he had read as a prescribed text while in school at St. John's College in Mthatha. Blurring the lines between oral and written text and emulating the notion of the 'common reader', I can still recall the main thrust of this tale without ever having personally read the book.

Though I don't remember there having been a library in our transit house in Charleston in Lusaka, Zambia, somehow, we had access to books. I remember this particularly since I was accosted by one of our commanders while immersed in Lloyd's Introduction to Jurisprudence. My commander seemed distraught about me reading bourgeois literature when I should have been immersed in Marxist-Leninist literature. This is how I came to know that "readers in exile chose material that suited their personal tastes instead of the dictates and ambitions of their political leaders" (Dick 109). Despite being aware that certain books were preferred in our exile community, we had unfettered access to all the books that were available to us.

In Tanzania we were dispatched to Dakawa, the most recent acquisition of land the ANC had secured from the Tanzanian government in 1982. Here we stayed at the Ruth First Education Orientation Centre. All new arrivals were housed at the orientation centre whilst, again, being processed. While the majority of us were en route to Solomon Mahlangu Freedom College (SOMAFCO), the school the ANC built in Mazimbu in 1977, 55 kilometres north of Dakawa, to continue our education, others were on their way to Angola for military training.

At the time of our arrival in the late 1980s, Dakawa was a rather drab place. It was still remarkably undeveloped with only a few old farm buildings and some newly built structures the comrades were busy erecting. We lived in tents in the orientation centre. However, we had a library, which was first housed in a tent and then a prefab building where we could borrow books, albeit from a very sparse collection of reading material (Morrow 517). Though things were tough in Dakawa during those days, we had books. It was here where I first encountered the works of South Africa and Africa's iconic writers like Sol Plaatje, Es'kia Mphahlele, Alex La Guma, Richard Rive, Dennis Brutus, Cosmo Pieterse, Peter Abrahams, Todd Matshikiza, Can Themba, Bessie Head, Miriam Tlali, Alfred Hutchinson, Z. K. Matthews, Mazisi Kunene, Chinua Achebe, Ngugi wa Thiong'o, Kofi Awoonor, Sembene Ousmane, Frantz Fanon, and others. Furthermore, being at the orientation centre, we were expected to read and study. Some of us were incredibly pleased to read material other than our second-hand textbooks.

In Dakawa, our days were spent working in our camp and studying. We also worked in teams or 'brigades' as they were called, attending to the various chores that needed doing. I was paired with my friend and cooked for the hordes of comrades at the orientation centre on an open fire in our ramshackle kitchen and dining hall. Given that the orientation center was mainly an education preparation camp, we had classes and were tutored under trees with chalk boards fastened or nailed to trees. Comrades who had been abroad to study and had returned were tasked with instructing us in basic school subjects. We were going to be tested on the traditional school subjects to determine our level of competency for placement in SOMAFCO. Also, SOMAFCO followed the British General Certificate of Education (GCE) curriculum all of us from South Africa needed to adjust to and master. The University of London was the examining body, which issued the certificates that enabled us to pursue university-level study across the globe. 
SOMAFCO had one intake of students a year, ostensibly to avoid disrupting the educational programme. You had to sit for the assessment before the next intake, and depending on when you arrived in Dakawa, you either had good time to prepare or you had to dive in at the deep end and sit for the assessment. Established on a former sisal farm in Mazimbu, which was initially occupied in 1977, SOMAFCO started in 1978 and formally opened in 1979 (Morrow, Brown and Pulumani 10). Unlike SOMAFCO, Dakawa was slated to serve "the need for a place where young people newly arrived from the south might stay until they could be received at SOMAFCO in an orderly way" (499). Dakawa would also, and among other things, provide the growing exile community technical and vocational skills in service of developing the settlement and for use in a liberated South Africa.

At the heart of the SOMAFCO campus was a remarkable library, fully stocked and manned by volunteers from our sympathetic international supporter nations and fellow South Africans. During my time at SOMAFCO, the head librarian was Marjatta Lahti, who the Finnish Library Association (FLA) sent to work in the library in 1985 (Dick 109). Lahti was assisted by other comrades like Maria Feralo (114). Unlike libraries I encountered before, I spent most of my time in the library at SOMAFCO reading books I took from the shelves. I simply enjoyed being in the library, which was contrary to my previous attitude towards libraries. I have often wondered whether this was because this library was 'our library' that it felt comfortable and inviting enough for me to occupy it as often as I could and wished.

I was amazed to discover Afrikaans books at SOMAFCO. From what seemed a long thirst, I devoured all I could lay my hands on in the Afrikaans books that were available. There were Afrikaans titles such as Breyten Breytenbach's Lewendood, Gerrit Olivier's Praat met die ANC, Dan Roodt's Twee sinne, and Pieter Dirk Uys's Die van aardes van grootoor, as referenced by Dick (119). The library also offered programming and workshops related to literacy and associated activities. It was here that I had my first writing workshop led by Eddie Dladla, my class teacher who was a poet and who I would also later learn was my mother's cousin, and Keorapetse Willie Kgositsile, who would become the South African Poet Laureate in a free and democratic South Africa. These workshops were instrumental in my writing life, which now spans more than three decades.

"There was a news reading session every evening followed by comments and discussion" (Dick 121) to keep us abreast of developments in the world and in South Africa. We "also had [our] own newspaper on campus called the Student Journal, which was 'an important medium for the expression of student views on politics,' and a News and Information Committee of the Student Union [that] collected news" (121). For us, "radio was an important source for news of political developments, but so were newspapers and current affairs magazines" (121). At SOMAFCO, we were taught by teachers from Africa, Europe, the US, Australia, the GDR (the former German Democratic Republic or East Germany), and others. At one point all our physics, chemistry, and biology teachers had PhDs. In addition, Dr. John Pampallis, author of Foundations of the New South Africa (1991), taught us history at SOMAFCO (Kearsney College Old Boys). Our primary text was Francis Meli's South Africa Belongs to Us: A History of the ANC and Viktor Afanasyev's Dialectical Materialism was our text for the Development of Society.

During this time, I also acquired a few books, which included a much-prized collection of poetry by Alexander Pushkin, Pushkin: Collected Poems 1813-1820. When I left Zambia for the US to study at Rutgers University in New Jersey in 1990, I had a really small suitcase of clothes and an even smaller box of books I took with me to my new frontier of struggle. I left for the US through Zambia because after 'graduating' at SOMAFCO, my comrades and I went to Zambia where I had a stint working for Dr. Seretse Choabe, the Director of the ANC's Education Department, while organising our means to get to the US. Choabe and I had had a fallout when he came to address us at SOMAFCO. I publicly challenged some aspect of his talk, which displeased him to such an extent he summoned me to the principal's office to dress me down and put me in my place.

Having forfeited the ANC's support, we had to sell our clothes to fund our way to Lusaka. We bartered with the locals in the Morogoro market and raised enough money to fund our trip to Zambia by train from Dar es Salaam via Mbeya. When we got to Lusaka, I visited the Education Department to use their computers to write letters to my uncle and aunt in New York, seeking their assistance with our precarious situation. Choabe walked into the building to find me typing away on an Apple Macintosh desktop computer. I had learned to use computers and to write computer programming language - dBASE at the time-while at SOMAFCO. Due to my writing interests, I had also taken a secretarial typing course on offer to help me with my writing, which enabled me to take the mini manual typewriter we used in class to my room on weekends to write.

Choabe found me touch typing away on the computer and demanded I come work for him. I reminded him about our previous encounter, whereupon he simply acknowledged that he knew I was that cheeky boy from 
SOMAFCO. He hired me on the spot as his Personal Assistant. During my time in the department, I assisted with composing and typing his official statements and reports. I also assisted him with his academic articles and speeches. Choabe had a PhD from Oxford University and led a staff that included the late Duma Nokwe's widow we simply called Ma Nokwe and Freddie Ramaphosa, a historian trained in Moscow who is also the brother of President Cyril Ramaphosa. Through my aunt and her networks in the US, I was able to secure a tuition waiver scholarship at Rutgers University in Camden, New Jersey. I left for the US in 1990 with the promise to organise to have my comrades join me to make up for jeopardising their chances of getting a scholarship through the ANC.

\section{Libraries, books, reading, and writing at university}

When I arrived at Rutgers University and saw their massive library, which was also in the heart of the campus, I fell in love all over again. Because I only had a tuition waiver scholarship, I had to raise the rest of the money I needed for my studies in the US and to bring my fellow comrades I had left behind over as promised. I worked the entire time I studied at university to earn the money for my obligations to the university and traversed the tri-state area (New Jersey, Delaware, and Pennsylvania) on speaking engagements to raise the money for my compatriots. My first job at Rutgers was in the library, which I quickly grew attached to. I ended up working with my fellow student leaders in the Black Student Union on campus to rename the library in honour of Paul Robeson, the great American intellectual, political leader, and cultural path-breaker (Editors of Freedomways 3-8). Robeson was a remarkable Rutgers University alum whose life and struggles impressed me greatly and resonated with my experiences.

While I was totally floored by the library on campus, I was startled to discover they did not have the Heinemann African Writers Series collection. I promptly visited the director of the library to ask about this anomaly. Without batting an eye, he asked that I get working on putting together such a collection and provided me with the necessary budget. During my time at Rutgers, where I studied and later worked, I collected books. It was among the stacks at the Paul Robeson library that I first discovered Leonard Thompson's A History of South Africa and Allister Spark's The Mind of South Africa. Having read Bloke Modisane's work in SOMAFCO, I had been searching for his autobiography, Blame Me on History, for almost seven years when I finally found a copy of it in a one-dollar-sales bin in a bookshop in Mount Laurel in South Jersey. Apart from collecting and reading books, I also wrote and published while at Rutgers. I was editor-in-chief of the Rutgers-Camden student newspaper, The Gleaner, as well as the Quintessence, the student literary magazine. I also published an opinion piece and an article in the Philadelphia Inquirer and Philadelphia Inquirer Magazine, respectively, which in 1993 was the tenth largest newspaper in the US.

Uncle Eddie, who was my class teacher at SOMAFCO, and his wife, Carole, who was my English teacher, were on sabbatical teaching at SOMAFCO as part of their support and contribution to the struggle. During her previous sabbaticals, Carole had also worked in the library at SOMAFCO. It was when I discovered that Uncle Eddie was a relative that I think I set my mind on going to the US. Eddie and Carole had a substantial collection of South African literature in their apartment in Manhattan, which made for endless conversations about literature, South African writers, and the struggle every time I visited them. It was during these visits that I read Eddie's poems in The Word is Here: Poetry from Modern Africa.

While I never really intended on having a family, developments in South Africa from 1990 onwards fundamentally changed my prospects. After the release of Nelson Mandela and the unbanning of our political organisations, it did not seem too farfetched that I, too, could have a normal family life. I subsequently met a fellow South African from Soweto in Philadelphia while studying. After graduating, we tied the matrimonial knot and had a son and a daughter. Being married and having a family, we relocated to West Mount Airy in suburban Philadelphia where we spent our weekends visiting Borders Bookshop and other second-hand book dealers. Our son had his own library at home. We never visited a bookshop without finding something for us to read to him as part of our modern family ritual of reading to our children. When his sister came along, she inherited a wellstocked children's library from her brother, which she, unlike him, mostly ravished on her own.

\section{Libraries, books, and reading in a new South Africa}

When I returned permanently to South Africa in 1999, I shipped a personal library back home as part of repatriating what I had accumulated in the US over the nine years I spent in that country, which was the longest I had lived in one single place during all my years in exile. Not having stopped buying books, I now have a formidable library of 
a few thousand volumes. I once tried to count the books I had in my library but eventually stopped when I passed the 3,000 mark. I then purchased a computer programme I used to catalogue 2,201 books in my collection. But because I continue to add books to the collection, I have never been able to completely get a handle on precisely how many volumes I own. However, from a more recent attempt, I counted roughly 5,750 books, which includes the three books I bought recently: C. W. de Kiewiet's The Anatomy of South African Misery, F. A. van Jaarveld's ' $n$ Inleiding tot die studie van Geskiedenis: Nege voorlesings vir voorgraadse studente, and Tim Keegan's Dr. Philip's Empire: One Man's Struggle for Justice in Nineteenth-Century South Africa.

My personal library provides me great pleasure. Again, this is strange because I had not really considered myself a book lover. I read, yes. But I read to know and not necessarily just for mere pleasure as I imagine a book lover would. When I tried to read for pleasure, I had to consciously buy books that were solely for entertainment like suspense, espionage, or crime novels. For this I collected books by Jack Higgins, Robert Ludlum, Michael Connelly, David Baldacci, John Saul, and Deon Meyer, among others. Subconsciously reflecting my abiding interests, my collection is heavily biased towards history and literature-South African, African, and African American history and literature.

And as if wishing to spread my affliction, I helped build libraries in schools in Mamelodi, Pretoria, the community where the university campus I work on is located. It would not be ostentatious to claim that all the fully stocked libraries in the primary schools in Mamelodi were built and stocked through a UK-based NGO I was associated with. I also used my Rutgers University networks to donate books from the US that we used to stock these libraries. My personal library also proved to be a living resource for me and others. Though I have had several students borrow books from my library for their studies, my greatest pleasure was when my wife, doing her PhD in Town and Regional Planning, used my library for her dissertation. I, too, have used my library for my own study and writing projects.

\section{Conclusion}

As I have come to recognise the utility of libraries, books, and reading as Dick reveals in The Hidden History, my life history echoes his assertions. Reading Dick's book through the lens of my life history, I locate my own story in the larger story of my people and our journey to the here and now. The Hidden History is indeed an unveiling of the varied and layered meanings we made under trying circumstances. As such, Dick is wholly correct in demanding that "township readers and librarians [...] deserve mention in the history of the liberation struggle" (1ll). Before encountering The Hidden History, I would never have described myself as someone who loves libraries and books. As revealed in reading The Hidden History, libraries and books have had what I have now come to learn is an instrumental role in my life. Dick has done a remarkable job documenting how books and reading have informed and shaped our sense of being and life from the beginning of our encounter with this technology on our shores and our struggle for our humanity. There are many things I have come to treasure in the life I have traversed thus far. Many of these have augmented me like an adjective modifies a noun as proffered by Charles King. Among these, however, libraries and books are topmost.

\section{Notes}

1. According to an obituary in The New York Times of 4 October 1999 by The Associated Press, Heinz G. Konsalik was born Heinz Gunther in Cologne, Germany. He was one of the most popular post-war novelists in Germany, whose books have sold more than 80 million copies worldwide. He died at the age of 78, having published his first book in 1953 under his mother's maiden name, Konsalik, and wrote more than 150 novels. His books were translated into 42 languages.

\section{Works cited}

Adriansen, Hanne K. "Timeline interviews: A tool for conducting life history research.” Qualitative Studies, vol. 3, no. 1, 2012, pp. 40-55.

Associated Press. "Heinz G. Konsalik, 78, German Novelist.” The New York Times. 4 Oct. 1999.

Dick, Archie L. The Hidden History of South Africa's Book and Reading cultures. U of Toronto P, 2012.

Editors of Freedomways. Paul Robeson: The Great Forerunner. Dobson, 1978.

Goldstone, Carvin. "Honour our Indian heroes." IOL. https://www.iol.co.za/news/politics/honour-our-indian-heroes-356782.

Hengeveld, Richard \& Jaap Rodenburg, eds. Embargo: Apartheid's Oil Secrets Revealed. Amsterdam U P, 1995.

Hofmeyr, Isabel. "Review: The Hidden History of South Africa's Book and Reading Cultures by Archie L. Dick." African Studies Review vol 57, no. 3, 2014, pp. 215-16.

Kearsney College Old Boys. “John Pampallis.” https://www.kearsney.com/oldboys/kearsney-college-old-boys/notablealumni/john-pampallis/. Accessed 20 July 2020. 
Magaziner, Daniel. "Review: The Hidden History of South Africa's Book and Reading Cultures by Archie L. Dick." The American Historical Review vol. 119, no. 3, 2014, pp. 1023-4.

Morrow, Seán. "Dakawa Development Centre: An African National Congress Settlement in Tanzania, 1982-1992." African Affairs vol. 97, no. 389, 1998, pp. 497-521.

Morrow, Seán, Brown Maaba \& Loyiso Pulumani. Education in Exile: SOMAFCO, the ANC School in Tanzania, 1978 to 1992. HSRC, 2004.

Slater, Rachel. "Using life histories to explore change: women's urban struggles in Cape Town, South Africa." Gender and Development vol. 8, no. 2, 2000, pp. 38-46.

South African History Online. "Leon Lionel Meyer." South African History Online. https://www.sahistory.org.za/people/leonlionel-meyer. 